\title{
E-Learning As A Career Path In Information Systems Curricula: A Blue Ocean Opportunity
}

Robert J. Mills, Ph.D., Utah State University, USA

Kelly J. Fadel, Ph.D., Utah State University, USA

\begin{abstract}
E-learning is a rapidly growing industry with emerging career opportunities that require expertise in business, information technology, and instructional design. However, most academic institutions lack cohesive programs for preparing students for e-learning careers. We argue that information systems (IS) programs have a unique, "blue ocean" opportunity to prepare students for e-learning careers with nominal curricular adjustment. This paper builds on the MSIS 2006 model curriculum to describe an approach for incorporating e-learning as a career track in information systems (IS) graduate programs. An example e-learning curriculum from a large, public university in the western United States is also presented. We believe that an e-learning IS career track can enhance the appeal of the IS major by providing students with access to a multibillion dollar industry and opening additional employment opportunities as they prepare for a career in business.
\end{abstract}

Keywords: Information Systems Curriculum; Career Tracks; E-Learning; MSIS 2006 Curriculum Model

\section{INTRODUCTION}

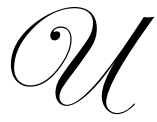

sing technology to improve business processes is a central purpose of information systems. Firms are increasingly recognizing the important role of e-learning, which uses technology to improve business processes and to help the company gain competitive advantage. Defined as training delivered on a computer to support individual learning or organizational performance goals (Clark and Mayer, 2003), e-learning is often credited for saving money, reducing travel time, increasing access to experts, and enabling self-paced learning which eliminates barriers of time, distance, and socioeconomic status (Turban, King et al., 2006). For instance, Cisco System's IOS Learning Services team has developed over 100 e-learning courses and expects to save millions of dollars every year implementing e-learning solutions (Turban, King et al., 2006). Benefits like these have made elearning a fast growing, multi-billion dollar industry with recent statistics projecting that it will continue to grow at an increasing rate. Career opportunities also continue to grow in this sector. Fisher (2005) classifies the profession of training \& development specialists as one of the 20 fastest-growing professional jobs in the next ten years with an expected increase of over $20 \%$. "Formal learning now plays a greatly diminished role, being supplanted by activitybased and technologically-based learning" (McGuire and Gubbins, 2010, p. 249).

Despite the rapid growth of the e-learning industry, most educational institutions lack consolidated and comprehensive curricula for training e-learning professionals. Traditionally, students interested in corporate training have earned degrees in over 20 academic fields ranging from agriculture to theater arts with a significant percentage having a master's degree (Anon., 1995). Unfortunately, many of these programs are limited in providing a technical background and do not necessarily prepare students to compete for many e-learning positions that are available. For example, one senior manager position listed on Monster.com was seeking expertise in instructional design of elearning solutions as well as intermediate skills in webpage development (i.e., HTML, XML, CSS, Java Script, and AJAX) (Monster.com, 2011). Ideally, e-learning students should be trained in instructional design, business, and systems theory, coupled with a strong foundation in information technology (Patel, 2010). "As e-learning moves 
into the training mainstream, training professionals need to learn new skills to exploit this different delivery mechanism" (Milne, 2005, p. 1).

The purpose of this paper is to describe how information systems (IS) program curricula can be tailored to prepare students for careers in e-learning. The motivations behind this objective are twofold. First, we believe that the distinctive characteristics of IS programs coupled with the rapid growth of the e-learning field provides a competitive opportunity for both IS students and IS programs, or what Kim and Mauborgne (2005) call a "blue ocean, defined by untapped market space, demand creation, and the opportunity for highly profitable growth" (p. 4). IS programs are uniquely positioned to exploit this blue ocean potential to create additional career opportunities for their students, all while requiring minimal additional department resources. Second, we believe that a career path in e-learning will enhance the appeal of an IS degree among prospective students. It is well known that IS departments have recently experienced a sharp downturn in the number of enrolled IS majors (Choudhury, Lopes et al., 2010; Ferratt, Hall et al., 2010). Students, particularly women, may turn away from IS as a major due to fears of job outsourcing and perceptions that IS jobs require long hours in front of the computer with little social interaction (Harris, Cushman et al., 2009; Scott, Fuller et al., 2009). E-learning careers offer high levels of social interaction, and rely on outsourcing-resistant skills such as interpersonal communication, business knowledge, project management, and the application of information systems to improve business processes. Promoting e-learning as a rewarding IS career track is a promising way for IS programs to attract students and combat the recent enrollment crisis.

The rest of this paper is organized as follows: We begin by identifying the areas of core competency required of students seeking e-learning careers. Utilizing the blue ocean strategy canvas (Kim and Mauborgne, 2005), we then describe how current academic pathways toward e-learning careers address (or fail to address) each of these competency areas. Finally, we draw from an IS model curriculum (Gorgone, Gray et al., 2006) to show that IS programs are strategically positioned to prepare students for e-learning careers with minimal additional department resources.

\section{CORE COMPETENCIES FOR E-LEARNING CAREERS}

Organizational training programs increasingly use technology-based training methods such as online simulations, mobile learning, social networks, and podcasts to complement traditional methods (Bell, Martin et al., 2004; McGuire and Gubbins, 2010; Patel, 2010). Citing an ASTD/i4cp Instructional Systems Design Study, Patel (2010) identifies subject matter expertise, information technology, project management, instructional design, and specific tool expertise as the most critical competencies necessary to implement these technology-based solutions. Each of these competencies is briefly discussed below:

\section{Subject Matter Expertise (Business Foundations)}

E-learning content varies across industries. For instance, in banking, common courses include "retail, small business, wealth management and trust, compliance, and management development areas" (Simmons, 2006, p. 18). Other common business-related e-learning topics include project management, customer service, and business communication (Meeker, 2011). Although it may be unrealistic for e-learning professionals to be deep experts in all dimensions of business-related training, there are clear benefits to having an operational understanding of the business fundamentals that underlie e-learning courses. Organizations implementing training solutions to quickly improve business processes need "professionals with an in-depth knowledge of learning theory and business problems to direct larger development projects" (e-learning.com, 2011). Moreover, Shepherd (2006) argues that having a subject matter expert involved in the design and development of training programs can help to streamline the process by reducing content review and approval processes. Equipping e-learning graduates with a background in business foundations such as accounting, finance, management, and marketing will help them better communicate with business stakeholders and design training programs specifically targeted to meet business objectives. 


\section{Information Technology}

Information Technology (IT) "refers to the products, methods, inventions, and standards that are used for the purpose of producing information" (Kroenke, 2008, p. 16). From an organizational information systems perspective, IT includes telecommunications and architecture as well as technology management and strategy. IT is an essential component of e-learning, which relies on technical infrastructure that must be implemented and managed within an organization's overall IT strategy. Thus, fundamental understanding of both technical and managerial aspects of IT is an important dimension of an e-learning professional's expertise. As noted by Williams (2009, p. 16), "companies usually prefer that [e-learning] candidates have additional competencies that technical professionals may already have, such as expertise in computer networking, learning management systems (LMS), elearning, and Web site development."

\section{Instructional Design}

Graduates in e-learning programs benefit from a solid foundation in instructional design theory, as "the technical skills mentioned don't do much good unless they are used by someone who also has some knowledge of instructional design" (Williams, 2009, p. 16). Instructional Design is defined as "the process of specifying conditions for learning" (Seels and Richey, 1994, p. 30). Following Merrill's premise that "information is not instruction" (Fryer, 1998, p. 25), instructional designers specify conditions for learning and create effective, motivating, and purposeful instruction that provides context for unorganized data and information. Four fundamental components of the instructional design process include learners (for whom is the program developed?), objectives (what do you expect the learner to achieve finally?), instructional strategies (how will you help learners meet their objectives?), and evaluation procedures (how do you determine whether learning objectives are met?). These four elements form the model for systematic instructional planning (Morrison, Ross et al., 2001).

\section{Project Management}

Project management is defined as "the application of knowledge, skills, tools, and techniques to project activities to meet project requirements" (Schwalbe, 2009, p. 441), and "is essential for success in all IS endeavors" (Gorgone, Gray et al., 2006, p. 18), including e-learning implementations. Project management skills are essential to avoiding e-learning project failure (Lynch and Roecker, 2007). As noted by Layng (1997, p. 19), "by understanding the delicate balance between project management and instructional design, a designer can explore the benefits of a systematic approach... Project management can help designers stick to detail yet remain cognizant of the entire project."

\section{Specific Tool Expertise}

Tool expertise includes learning specific software to help solve a particular problem. As the use of technology in learning continues to increase, demand for knowledge of specific tools will become increasingly important to e-learning projects (Schweizer, 2004; McGuire and Gubbins, 2010). Common technology skills demanded of e-learning specialists include: XHTML, CSS, Flash, Authorware ${ }^{\mathrm{TM}}$, DreamWeaver ${ }^{\mathrm{TM}}$, ASP.NET, SQL, Java Script, XML, Flash ${ }^{\mathrm{TM}}$, Networking, and Cold Fusion (Shepherd, 2009; Williams, 2009). This trend supports the idea that graduates who plan on working in the e-learning area need training in specific information technology tools such as programming and web development. This list is consistent with demanded skills in IS such as web applications, data management, and wireless communications (Lee and Mirchandani, 2010).

\section{CURRENT ACADEMIC OFFERINGS FOR E-LEARNING}

Given the core e-learning competency areas identified above, we now turn our attention to academic programs commonly associated with e-learning careers. A majority of training professionals hold degrees in business, education, and the social sciences (Anon., 1995). Degrees in human resources or instructional technology programs are widely accepted as qualifying academic backgrounds for the training profession. However, these programs may be limited in providing a technical background and, consequently, do not necessarily prepare students to compete for many e-learning positions that are available. One way to characterize the "fit" of 
these programs with the needs of e-learning graduates is through the use of a blue ocean strategy canvas (Kim and Mauborgne, 2005).

We utilize the strategy canvas framework in this paper to characterize the "competitive offerings" of traditional instructional technology and human resources curriculum for training e-learning professionals. In this context, the aim of the strategy canvas is to show which of the e-learning competencies is currently addressed by the existing curricular models. To assess this, we reviewed the courses offered by instructional technology and human resources programs at a large, public, accredited university and mapped these courses to the five e-learning competencies identified above. Any competency that was substantively covered by at least three courses in the curriculum was labeled "high"; competencies covered by one or two courses were labeled "medium"; and competencies not covered by any course were labeled "low." The complete course-competency mappings are shown in Appendix A. Figure 1 describes the resulting strategy canvas for both instructional technology and human resources.

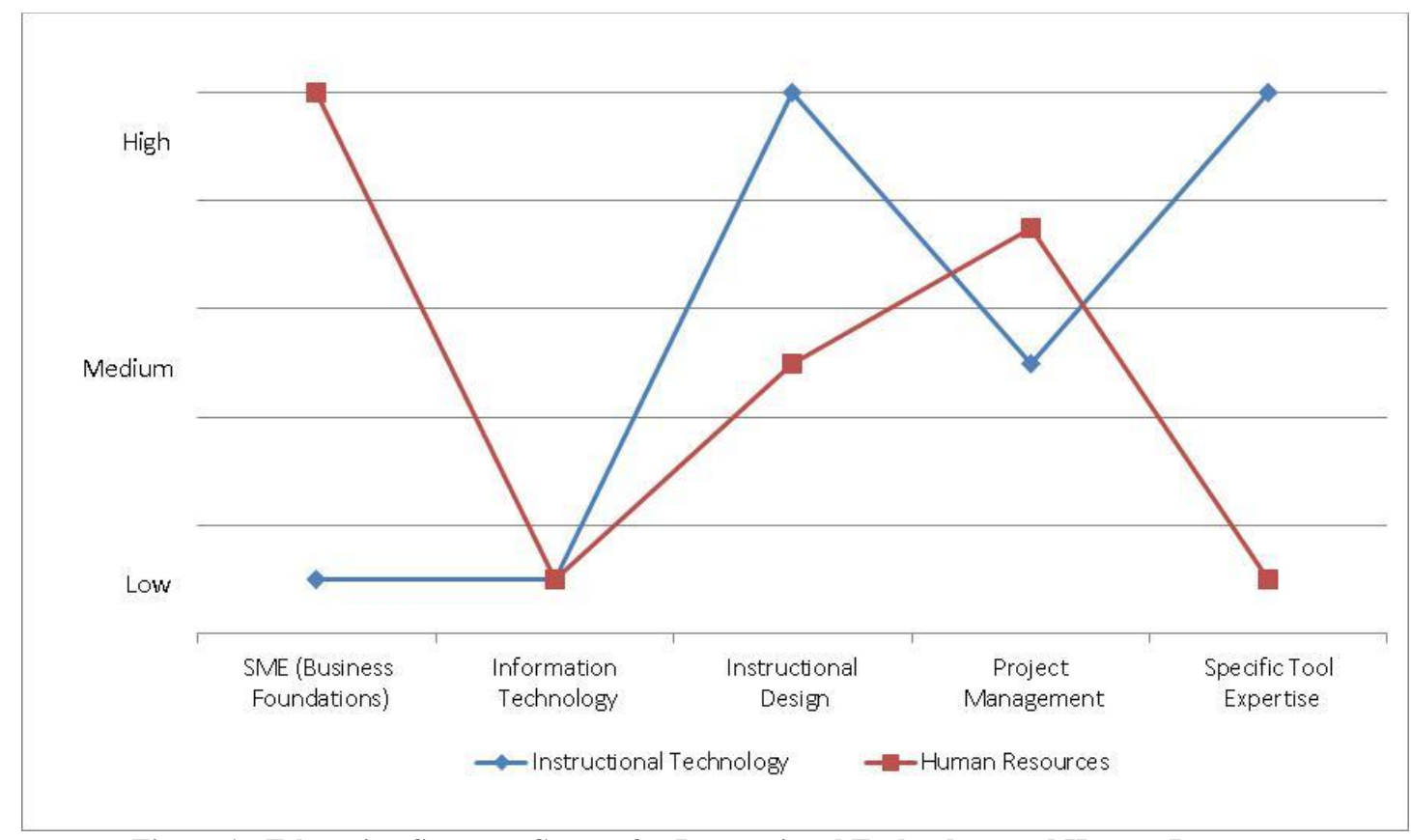

Figure 1: E-learning Strategy Canvas for Instructional Technology and Human Resources

As shown in Figure 1, instructional technology scored highest on instructional design and specific tool expertise, while human resources scored highest on business foundations. However, both scored relatively low on information technology. Thus, students graduating in human resources and instructional technology should be equipped with some of the identified e-learning competencies (design theory, business foundations), but may lack other competencies such as information technology or specific tool expertise. An ideal academic program for elearning would provide strong preparation in these technology-related areas while offering comparable exposure to business and instructional design. The following section shows how IS programs are well positioned to fulfill these requirements.

\section{E-LEARNING IN THE IS CURRICULUM}

Having outlined the limitations of current academic preparation for e-learning careers, we now describe how e-learning can be integrated as an area of focus in an IS program ${ }^{1}$. Because many training and e-learning positions require a graduate degree, we focus our attention on master's degree in information systems (MSIS)

\footnotetext{
${ }^{1}$ Our analysis is based on IS programs that are housed within business schools or that integrate business components into the
} curriculum. 
programs. However, our analysis could also apply to undergraduate IS programs, for which extant model curriculum guidelines recommend many similar components (Brookshire, Hunt et al., 2007; Topi, Valacich et al., 2010).

To guide our analysis of how e-learning fits within an IS curriculum, we draw from the MSIS 2006 model curriculum (Gorgone, Gray et al., 2006). This curriculum was organized as a set of interrelated building blocks that include foundations, core (technical and managerial), an integrated capstone, and career tracks. "The objective of a model curriculum is to provide a guideline for program designers for specifying a minimum common body of knowledge for all MSIS graduates...Individual programs may vary from the recommended model because each institution is different in scope, emphasis, faculty resources, and student skills, and serves different employer constituencies" (Gorgone, Gray et al., 2006, p. 8). The design of the MSMIS 2006 model is intended to be flexible and can be "tailored to meet individual needs and at the highest level where institutions and students may select specific career tracks that are representative of current organizational needs" (Gorgone, Gray et al., 2006, p. 7).

Comparing the skills of MSIS graduates with the core competency areas of e-learning graduates reveals a significant degree of overlap between the skill sets. IS \& Business Foundations in the MSIS 2006 model curriculum closely match the subject matter expertise (business foundations) and information technology competency areas for e-learning careers. Similarly, the MSIS 2006 IS Management \& Technology skill set corresponds with the specific tool expertise and project management required of e-learning professionals. The correspondence between e-learning and MSIS skills is further confirmed by performing course-to-competency mapping as done above for instructional technology and human resources. The third row of the table in Appendix A shows how the courses described in the MSIS model curriculum correspond with the identified e-learning competencies. The resulting strategy canvas is shown in Figure 2.

As shown the figure, IS scores high on subject matter expertise (business foundations), information technology, and specific tool expertise. However, it scores lower than both human resources and instructional technology on instructional design, which does not have a corresponding component in the MSIS model curriculum. Because instructional design is a crucial component of e-learning (Williams, 2009), this is not an insignificant weakness. However, we believe that this deficiency can be readily addressed through the third specialized skill area in the MSIS 2006 curriculum model: career electives. The next section describes how each component of an elearning-focused IS curriculum can be implemented.

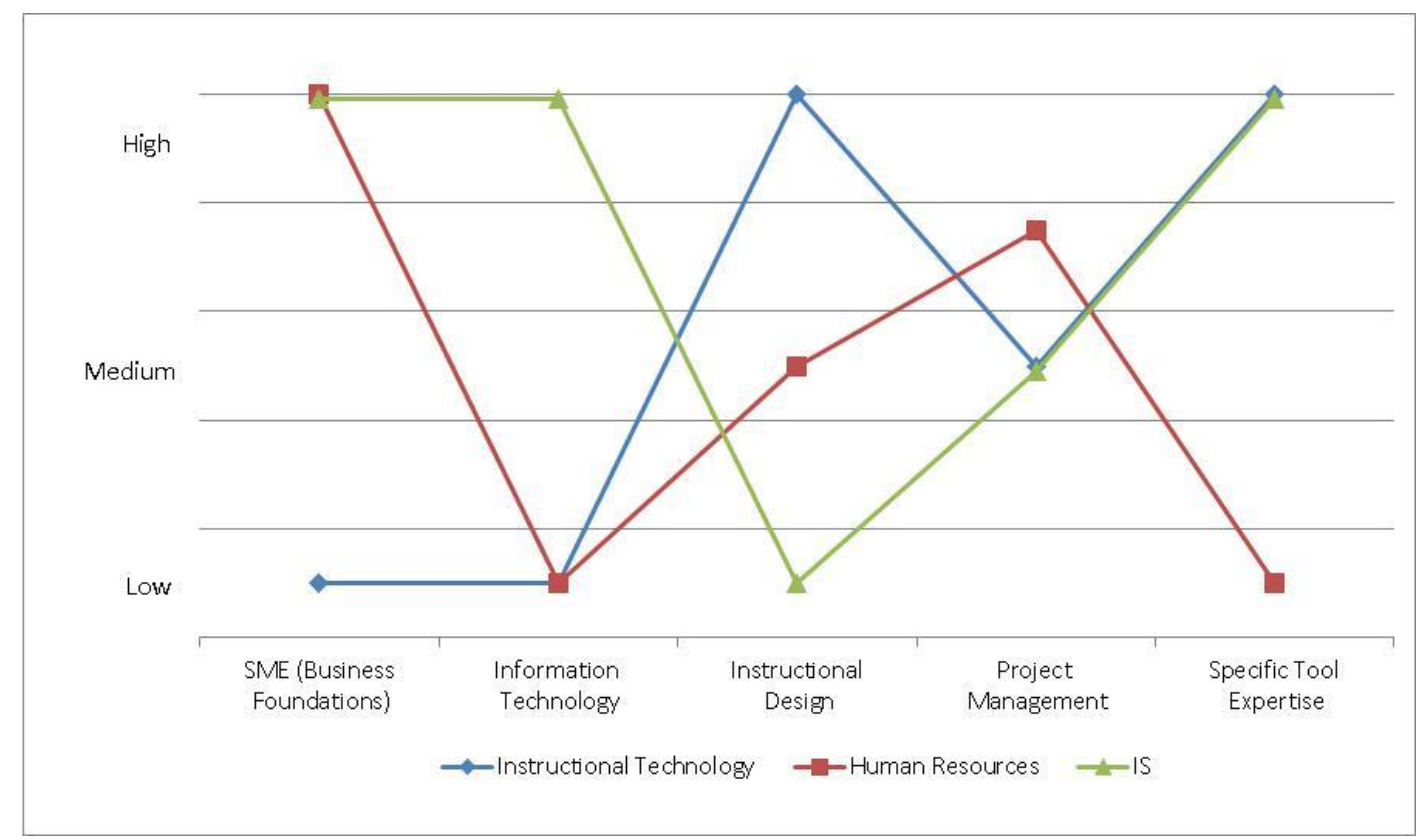

Figure 2: E-learning Strategy Canvas for Instructional Technology, Human Resources, and IS 


\section{ESTABLISHING E-LEARNING IN IS}

In the MSIS model curriculum, the knowledge and skills are realized in practice via a series of interrelated components that constitute the whole of the curriculum. The bottom two components, IS and Business foundations, are implemented through a series of up to five courses covering topics such as fundamentals of IS; programming, data, file and object structures; financial accounting; consumer-focused marketing; and organizational behavior. For an e-learning graduate, these courses provide foundational knowledge in the subject matter expertise (business fundamentals) and information technology competency areas. Additionally, these courses allow students to gain expertise using specific technology tools, such as programming languages and integrated development environments. The specific set of courses suggested for these components is not canonical, and, as noted by Gorgone (2006, p. 14), "an institution may require more than this minimum in each of the foundation areas" or "may elect to allow a student to substitute professional experience for certain foundation courses." Thus, programs tailored to meet the specific needs of e-learning graduates may substitute more specialized courses (such as training for organizational performance improvement) for those listed above.

The third component is IS Management and Technology, which is implemented through a series of courses that focus on managing technology in organizations as well as various aspects of the technology itself. This component addresses the information technology, specific tool expertise, and project management competency areas of an e-learning graduate. Up to eight courses are recommended to implement this component as shown in Table 1.

Table 1: Recommended IS Management and Technology Courses/Topics (Gorgone, Gray et al., 2006)

\begin{tabular}{|l|l|}
\hline \multirow{4}{*}{ IS Technology } & IT Infrastructure (includes networking) \\
\cline { 2 - 2 } & Analysis, Modeling, and Design (includes Human-Computer Interaction and Data) \\
\cline { 2 - 3 } & Enterprise Models \\
\cline { 2 - 2 } & Emerging Technologies and Issues \\
\hline \multirow{5}{*}{ IS Management } & Project and Change Management \\
\cline { 2 - 2 } & Strategy and Policy \\
\cline { 2 - 2 } & Implications of Digitization OR \\
& Human-computer Interaction \\
\cline { 2 - 2 } & Integrated Capstone \\
\hline
\end{tabular}

As shown in the table, the courses within the IS management and technology component expose e-learning graduates to both broad information technology issues (e.g., enterprise IT models, implementation, strategy \& governance) as well as specific technology tools (e.g., database management systems, interface design software). Additionally, this component introduces students to project and change management, a critical component of successful instructional design (Layng, 1997; Lynch and Roecker, 2007). As with the foundational courses, the specific content and sequence of these courses can be adjusted according to specific student needs and faculty expertise. A human-computer interaction course for e-learning graduates, for example, may place extra emphasis on the pedagogical implications of interface design for learning and pedagogy, while a systems analysis and design course might highlight task analysis methods for performance improvement.

The fourth component is the integrated capstone course. The purpose of the capstone course is to emphasize the integration of all other components learned in previous courses. Specifically, emphasis on integration at three distinct levels is recommended: the enterprise, the IS function, and the technologies. The enterprise level focuses on the enterprise as a whole, its value-generating business processes, and its relationships with suppliers and customers. This level emphasizes how IS should be aligned with the goals and objectives of the organization. The IS function level deals with the day-to-day management of technologies, and encompasses process design, evaluation of emerging technologies, human resources needs, and IS governance. Finally, the technologies level concerns the enterprise IT architecture along with the role of implementation standards and the impact of vendor strategies.

E-learning graduates can benefit in many ways from an integrated capstone course, particularly in the project management and business foundation competency areas. Most capstone courses involve comprehensive 
projects related to such areas as process redesign, knowledge management, performance improvement, and business intelligence. Such projects require students to manage project variables (scope, schedule, functional interdependencies) in the context of a business environment (competitive strategy, resource limitations, management support). The capstone course can, therefore, be instrumental in teaching e-learning students how instructional solutions developed at the operational business level relate to business objectives at functional and enterprise levels.

The final curriculum component is career tracks. Recognizing that the field of information systems is constantly changing, Gorgone, et al. (2006) note that the MSIS 2006 model is "designed to support both traditional and emerging career opportunities" (p. 11), and includes career tracks to allow "institutions and students [to] select specific career tracks that are representative of current organizational needs" (p. 7). As noted previously, e-learning clearly falls within the definition of an emerging career in high demand by today's organizations.

The career track component is implemented in the curriculum through a series of electives that prepare a student for a specialization (Gorgone, Gray et al., 2006). Gorgone, et al. (2006) note that these specializations may range from traditional (systems analysis and design) to cutting-edge (knowledge management, outsourcing), and they identify possible elective courses that could be associated with representative career tracks. Although elearning is not one of the identified tracks, the authors acknowledge that the list of careers they identify is not exhaustive and that there could be many more. Moreover, they note that many career tracks can (and should) be cross-disciplinary, a characteristic that clearly applies to e-learning.

What career track electives might be appropriate for IS graduates preparing for a career in e-learning? As noted above, one e-learning competency area in which the default IS curriculum is deficient is design theory. Courses such as training and organization development and instructional design theory offered by human resources and instructional technology would help to provide coverage of instructional design. In addition, IS departments might include some instructional design components in elective classes such as knowledge management, performance improvement, and human computer interaction.

Based on the discussion above, Table 2 shows a sample curriculum for an IS graduate preparing for a career in e-learning. The left column lists the MSIS 2006 curriculum components, and the right column lists the elearning competency areas. The middle column identifies specific topics/courses that should be included in the curriculum. Courses/topics in the career track component are those that would differ most explicitly from the courses taken by a traditional IS graduate. However, as noted above, other components of the curriculum might also be adjusted to emphasize skills for a specific career.

Table 2: Sample Curriculum for an E-learning IS Graduate

\begin{tabular}{|l|l|l|}
\hline \multicolumn{1}{|c|}{$\begin{array}{c}\text { MSIS 2006 Curriculum } \\
\text { Components }\end{array}$} & \multicolumn{1}{|c|}{ Courses/Topics } & \multicolumn{1}{c|}{$\begin{array}{c}\text { E-learning Competency } \\
\text { Areas }\end{array}$} \\
\hline Business Foundations & $\begin{array}{l}\text { AACSB Foundation Knowledge (i.e., accounting, finance, } \\
\text { management, business law) }\end{array}$ & $\begin{array}{l}\text { Subject Matter Expertise } \\
\text { (Business Foundations) }\end{array}$ \\
\hline IS Foundations & $\begin{array}{l}\text { IS2002.1 Fundamentals of Information Systems } \\
\text { IS 97.5 Programming, Data File and Object Structures }\end{array}$ & Information Technology \\
\hline IS Management \& Technology & $\begin{array}{l}\text { MSIS2006.1 IT Infrastructure } \\
\text { MSIS2006.2 Analysis, Modeling \& Design } \\
\text { MSIS2006.3 Enterprise Models } \\
\text { MSIS2006.4 Emerging Technologies and Issues }\end{array}$ & Specific Tool Expertise \\
\hline Capstone Course & MSIS2006.7 Integrated Capstone & Project Management \\
\hline Career Track & $\begin{array}{l}\text { Managing Performance Improvement Projects } \\
\text { Instructional Design Process I } \\
\text { Training and Organization Development }\end{array}$ & Design Theory \\
\hline
\end{tabular}

Based on the preceding discussion, Figure 3 shows how the strategy canvas of an e-learning IS graduate might compare with that of a traditional IS graduate. We anticipate that a student graduating with the set of courses above would possess business and information technology knowledge comparable to that of a traditional IS graduate. Because of the additional focus on instructional design afforded by the career track electives, such a 
graduate would also be highly proficient in this area. Of course, the tradeoff inherent in adding the design theory focus is that e-learning IS graduates may not take some of the additional technology or systems classes that their traditional IS counterparts would take for career electives. This result is that e-learning IS graduates may be slightly weaker in these areas, but will emerge with an overall balanced portfolio of skills that amply prepares them for a successful e-learning career. This degree could also provide a valuable academic background for students interested in a Ph.D. program either in IS or Instructional Technology.

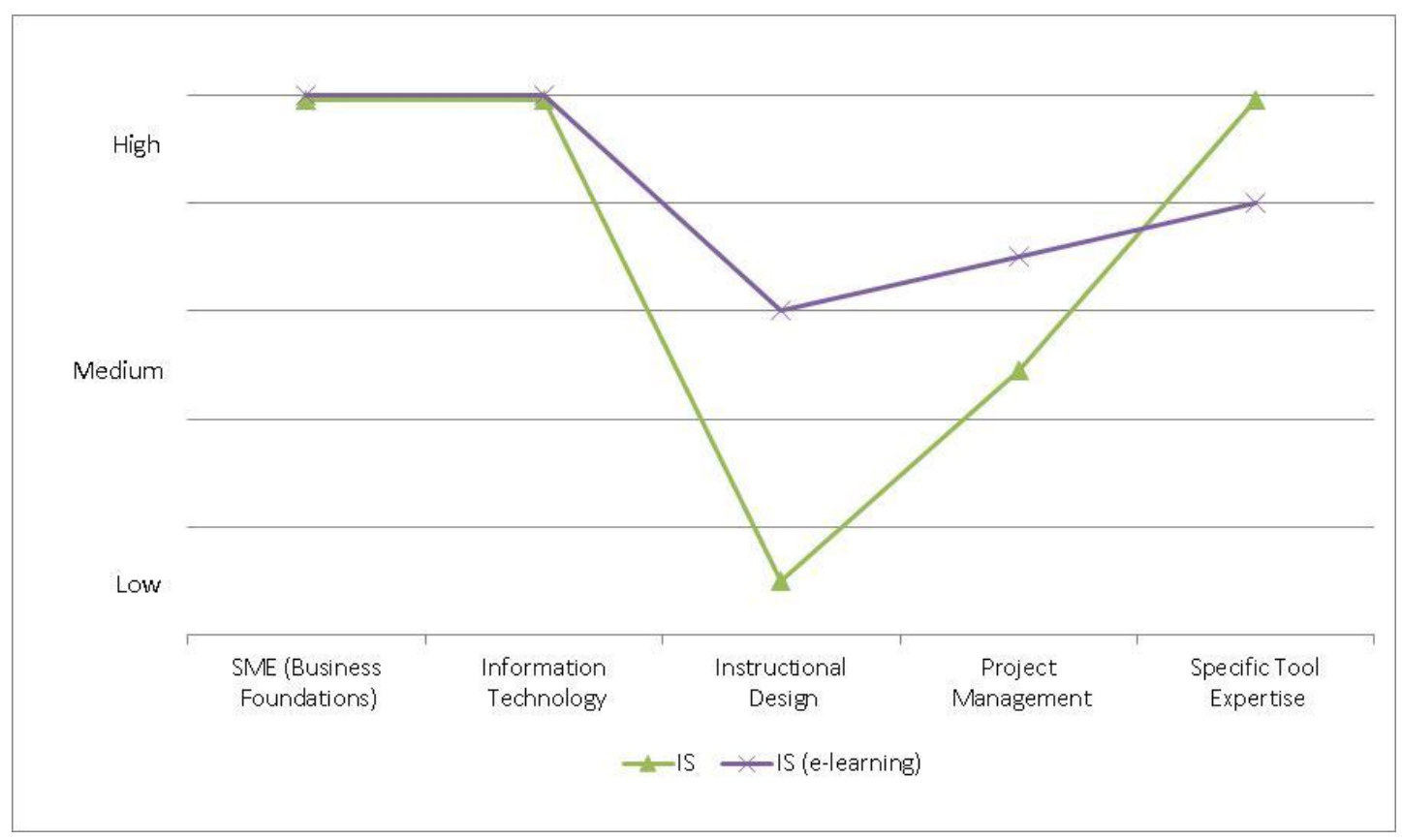

Figure 3: E-learning Strategy Canvas for IS (traditional) and IS (e-learning)

\section{CONCLUSION}

Academic departments including IS, Instructional Technology, Human Resources, and others each contribute unique preparation for students interested in careers in e-learning. Depending on the specific e-learning position being sought (i.e., focus on design or focus on development), one program may provide a better fit for a particular position. However, with an increasing demand for e-learning specialists, business schools (and information systems programs in particular) are uniquely positioned to successfully prepare students for careers in this emerging field by providing students coursework in information technology, business foundations, and systems design. Arguably, the missing link to a successful e-learning curriculum in many IS departments is instructional design theory. However, this limitation can usually be remedied by slight modifications to existing IS curriculum and/or electives offered through a different department on campus.

As noted earlier, we believe that a career path in e-learning can help to combat the IS enrollment crisis by widening the appeal of an IS department when recruiting students, particularly women and those who may be concerned about outsourcing. Business focus and project management skills are cited as "critical to keep in house while technical skills [are] cited as the top skills sourced" (Abraham, Beath et al., 2006, p. 1147). E-learning positions also require these outsourcing-resistant skills. In addition, negative perceptions among women include perceptions that a career in IT would mean sitting in front of computers all day with little social interaction (Harris, Cushman et al., 2009). Career opportunities in e-learning provide a unique opportunity for IS graduates with a genuine interest in solving business problems using business knowledge, project management skills, and information systems to improve business processes. IS career tracks in e-learning provide solid academic preparation for students interested in this career. As demand increases for graduates with IS skills to build cost-saving e-learning 
solutions, the future for IS graduates in e-learning appears to be very promising and represents a unique blue-ocean opportunity for IS departments.

\section{AUTHOR INFORMATION}

Dr. Robert J. Mills is associate professor of management information systems in the Jon M. Huntsman School of Business at Utah State University. His research interests include computer-based learning environments, knowledge transfer, and MIS education. Dr. Mills has consulted on technology-based training projects for a variety of organizations including EnergySoultions Arena/Utah Jazz, Silicon Graphics International (SGI), and IBM. E-mail: bob.mills@usu.edu. Corresponding author.

Kelly J. Fadel is an Assistant Professor of Management Information Systems at the Huntsman School of Business at Utah State University. He received his $\mathrm{PhD}$ from The University of Arizona. His research areas include knowledge management, end-user learning, and post-adoptive technology use. His research has appeared in journals such as Information Systems Research, Communications of the AIS, Data Base for Advances in Information Systems, and International Journal of Knowledge Management. His work has also been presented with recognition at several international information systems conferences. E-mail: kelly.fadel@usu.edu

\section{REFERENCES}

1. Abraham, T., Beath, C., Bullen, C., Gallagher, K. and Goles, T. (2006) "IT Workforce Trends: Implications for IS Programs," Communications of the AIS, Vol. 17, No. 1, pp. 1147-1170.

2. $\quad$ Anon. (1995) "How did you get your start in training?," Training \& Development, Vol. 49, No. 3, pp. 16.

3. Bell, M., Martin, G. and Clark, T. (2004) "Engaging in the future of e-learning: A scenario-based approach," Education and Training, Vol. 46, No., pp. 296-307.

4. Brookshire, R. G., Hunt, C. S., Yin, L. R. and Crews, T. B. (2007) "An End-User Information Systems Curriculum for the 21st Century," Journal of Computer Information Systems, Vol. 47, No. 3, pp. 81-88.

5. Choudhury, V., Lopes, A. B. and Arthur, D. (2010) "IT Careers Camp: An Early Intervention Strategy to Increase IS Enrollments," Information Systems Research, Vol. 21, No. 1, pp. 1-14.

6. Clark, R. and Mayer, R. (2003) E-Learning and the Science of Instruction. San Francisco, CA, JosseyBass/Preiffer, pp.

7. e-learning.com. (2011). "e-Learning Careers." Retrieved April 2, 2011, 2011, from http://www.aboutelearning.com/e-learning-careers.html.

8. $\quad$ Ferratt, T., W., Hall, S. R., Prasad, J. and Wynn, D., Jr. (2010) "Choosing Management Information Systems as a Major: Understanding the smiFactors for MIS," Communications of the AIS, Vol. 27, No. 1, pp. 265-284.

9. $\quad$ Fisher, A. (2005) "Hot Careers for the Next 10 Years," pp.

10. Fryer, B. (1998) "Powerhouses of Design: Roger Schank and M. David Merrill speak out on instructional design for the 21st century.," pp. 25-28, 53.

11. Gorgone, J. T., Gray, P., Stohr, E. A., Valacich, J. S. and Wingrand, R. T. (2006) "MSIS 2006: Model Curriculum and Guidelines for Graduate Degree Programs in Information Systems," Communications of the AIS, Vol. 17, No. 1, pp. 1-56.

12. Harris, N., Cushman, P., Kruck, S. E. and Anderson, R. D. (2009) "Technology Majors: Why are Women Absent?," Journal of Computer Information Systems, Vol. 50, No. 2, pp. 23-30.

13. Kim, W. C. and Mauborgne, R. (2005) Blue Ocean Strategy: How to Create Uncontested Market Space and Make the Competition Irrelevant. Boston, MA, Harvard Business School Press, pp.

14. Kroenke, D. (2008) Using MIS, Prentice Hall, pp.

15. Layng, J. (1997) "Parallels Between Project Management and Instructional Design," Performance Improvement, Vol. 36, No. 6, pp. 16-20.

16. Lee, K. and Mirchandani, D. (2010) "Dynamics of the Importance of IS/IT Skills," Journal of Computer Information Systems, Vol. 50, No. 4, pp. 67-78.

17. Lynch, M. M. and Roecker, J. (2007) Project Managing E-Learning: A Handbook for Successful Design, Delivery and Management. New York, Routledge, pp. 
18. McGuire, D. and Gubbins, C. (2010) "The Slow Death of Formal Learning: A Polemic," Human Resource Development Review, Vol. 9, No. 3, pp. 249-265.

19. Meeker, K. (2011). "The Top E-learning Topics for 2011." Retrieved April 2, 2011, from http://www.opensesame.com/blog/top-10-elearning-topics-2011.

20. Milne, J. (2005) "E-Learning: The New E-xperts," Haymarket Professional Publications Ltd., pp. $28-33$.

21. Monster.com. (2011). "Senior Manager of E-Learning." from http://jobview.monster.com/Senior-Managere-learning-Job-Parsippany-NJ-96711118.aspx.

22. Morrison, G., Ross, S. and Kemp, J. (2001) Designing Effective Instruction, John Wiley and Sons, pp.

23. Patel, L. (2010) "Instructional Systems Design in an On-Demand World," Training \& Development, Vol. 64, No. 12, pp. 42-44.

24. Schwalbe, K. (2009) An Introduction to Project Managment. Boston, MA, Course Technology, pp.

25. Schweizer, H. (2004) "E-learning in Business," Journal of Management Education, Vol. 28, No., pp. 674692.

26. Scott, C., Fuller, M. A., MacIndoe, K. M. and Joshi, K. D. (2009) "More than a Bumper Sticker: The Factors Influencing Information Systems Career Choices," Communications of the AIS, Vol. 24, No. 1, pp. 7-26.

27. Seels, B. B. and Richey, R. C. (1994) Instructional Technology: The Definition and Domains of the Field. Washington, DC, Association for Educational Communications and Technology, pp.

28. Shepherd, C. (2006) "Subject Matter Expters are Best for Rapid Design," pp. 31.

29. Shepherd, C. (2009) "From simple to sophisticated," pp. 16-17.

30. Simmons, H. H. (2006) "Training Matters," ABA Banking Journal, Vol. 98, No. 7, pp. 18-18.

31. Topi, H., Valacich, J. S., Wright, R., Kaiser, K., Nunamaker, J., Jr., Sipior, J. C. and de Vreede, G. J. (2010) "IS 2010: Curriculum Guidelines for Undergraduate Degree Programs in Information Systems," Communications of the AIS, Vol. 26, No. 1, pp. 359-428.

32. Turban, E., King, D., Viehland, D. and Lee, J. (2006) Electronic Commerce 2006: A Managerial Perspective. Upper Saddle River, NJ, Pearson Education, pp.

33. Williams, G. R. (2009) "Crossover Careers for Technical Professionals," Vol 11, pp. 14-18. 
Appendix A: Course Coverage Of E-Learning Core Competency Areas For Human Resources, Instructional Technology, And IS

\begin{tabular}{|c|c|c|c|c|c|}
\hline & $\frac{\text { Subject Matter }}{\text { Expertise }}$ & $\frac{\text { Information }}{\text { Technology }}$ & $\frac{\text { Instructional }}{\text { Design }}$ & $\begin{array}{c}\text { Project } \\
\text { Management }\end{array}$ & $\frac{\text { Specific Tool }}{\text { Expertise }}$ \\
\hline $\begin{array}{l}\text { Human } \\
\text { Resources }\end{array}$ & $\begin{array}{l}\text { High } \\
\text { - Accounting } \\
\text { - Finance } \\
\text { - Management } \\
\text { - Business Law }\end{array}$ & Low & $\begin{array}{l}\text { Medium } \\
\text { - Training \& } \\
\text { Organizational } \\
\text { Development }\end{array}$ & $\begin{array}{l}\text { High } \\
\text { - Human } \\
\text { Resource } \\
\text { Policy \& } \\
\text { Strategy } \\
\text { - Leadership and } \\
\text { Operational } \\
\text { Excellence } \\
\end{array}$ & Low \\
\hline $\begin{array}{l}\text { Instructional } \\
\text { Technology }\end{array}$ & Low & Low & $\begin{array}{l}\text { High } \\
\text { - Instructional } \\
\text { Design Process } \\
\text { I \& II } \\
\text { - Learning } \\
\text { Theory } \\
\text { - Instructional } \\
\text { Technology in } \\
\text { Adult } \\
\text { Education }\end{array}$ & $\begin{array}{l}\text { Medium } \\
\text { - Projects in } \\
\text { Instructional } \\
\text { Technology }\end{array}$ & $\begin{array}{l}\text { High } \\
\text { - Internet } \\
\text { Development } \\
\text { - Digital Video } \\
\text { Capture and } \\
\text { Production } \\
\text { - Interactive } \\
\text { Multimedia } \\
\text { Production }\end{array}$ \\
\hline $\begin{array}{l}\text { Information } \\
\text { Systems }\end{array}$ & $\begin{array}{l}\text { High } \\
\text { - Accounting } \\
\text { - Finance } \\
\text { - Management } \\
\text { - Business Law }\end{array}$ & $\begin{array}{l}\text { High } \\
\text { - IS Strategy } \\
\text { - Business Data } \\
\text { Communicatio } \\
\text { ns } \\
\text { - Security of } \\
\text { Information } \\
\text { Systems }\end{array}$ & Low & $\begin{array}{l}\text { Medium } \\
\text { - Business } \\
\text { Systems } \\
\text { Development }\end{array}$ & $\begin{array}{l}\text { High } \\
\text { - Advanced } \\
\text { Website } \\
\text { Development } \\
\text { - Management } \\
\text { of Database } \\
\text { Systems } \\
\text { - Developing } \\
\text { Systems with } \\
\text { Advanced } \\
\text { Software }\end{array}$ \\
\hline
\end{tabular}




\section{$\underline{\text { NOTES }}$}

